of Molecular Biology.

The potential market value of monoclonal antibodies and the lack of a satisfactory route for commercially exploiting them is well known to the MRC. At the end of February it asked its scientific staff to provide full information on the availability and characterisation of hybrid cell lines as they were produced. At the same time the MRC said that it was exploring the means by which such cells and the antibodies produced from them could be distributed and marketed in a coordinated way.

Questioned whether this represented a new departure in MRC policy, Dr James Gowans, MRC secretary, said that the policy was not new but that, under pressure from the Treasury, the possibilities of commercial exploitation were being looked at more aggressively. Many monoclonal antibodies produced in MRC laboratories are already being marketed through the small UK firm of Sera-Lab Ltd, with a proportion of the sales revenue being channelled back to the laboratories. But, said Gowans, the antibodies marketed by Sera-Lab tended to be those of marginal commercial value. For the development and marketing of antibodies of high commercial value either because of the anticipated volume of sales or because of the rarity of the cell hybrids from which the antibody was derived, Gowans would welcome the existence of a company of the kind that the NEB might start.

\section{Peter Newmark}

\section{Spinks offers "too little"}

THE chairman of Cetus Corporation, America's first and largest contract biotechnical enterprise, believes that $£ 2$ million a year for five years is far too little to invest in a new biotechnical firm - as envisaged in the Spinks report. Pressed as to what would be a reasonable investment, he suggested $\$ 50$ million over five years would be the minimum "if you are not to waste your cash".

The Cetus chairman, Dr Ronald Cape, was speaking at a conference on biotechnology in Rotterdam at the end of last month. He eschews government funding or work undertaken in universities outside Cetus's direct control. "We do our work in our labs"' he said.

Returns will be long in coming, thinks Cape: no genuine profit for 5 to 10 years. Nevertheless, Cetus "is now investing millions of dollars of its own money, and comparable amounts on behalf of major company clients," in biotechnology.

New companies like Cetus will move biotechnology forward, thinks Cape, but new companies are not necessarily small. Cetus has 250 employees - "the largest collection of molecular biologists in the world" - and 18 projects in five industries, all with potential markets of billions of dollars. "Biotechnology is no longer cheap" says Cape.

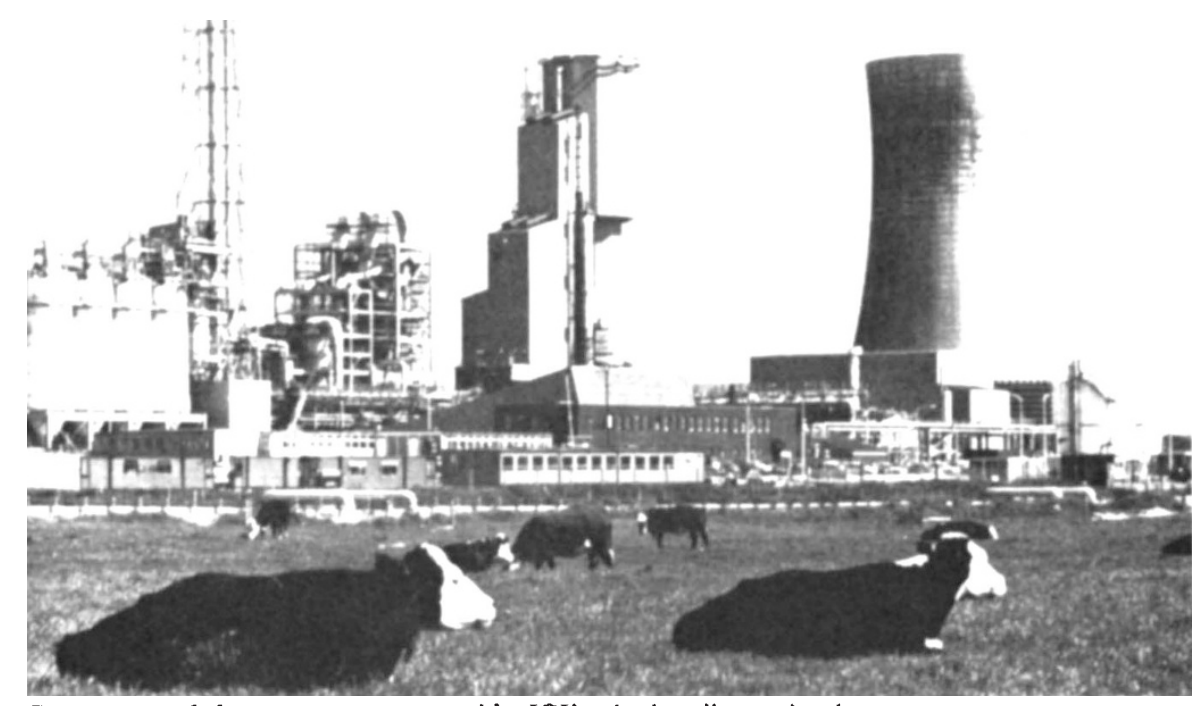

Two types of fermenter: cows outside ICI's single cell protein plant

\title{
Single cell protein organism improved
}

MicRO-ORGANISMS selected by the British firm Imperial Chemical Industries (ICI) to produce single cell protein (SCP) have been made more carbon-efficient by an application of recombinant DNA techniques, the firm announced last week.

ICI recently established the world's largest SCP fermenter - more than $50 \mathrm{~m}$ high - using a methanol-consuming organism known as AS1. But the process has been under constant market pressure from agriculturally-produced soya-bean protein (both are used as animal feed supplements) and so ICI has been at pains to reduce the basic cost of its SCP. One obvious target was to improve the efficiency with which AS1 converts the costly methanol feedstock into protein.

Protein requires nitrogen, and AS1 gets its nitrogen from ammonia. But ICI discovered that AS1 assimilates the ammonia by an energy-inefficient pathway - one using the enzyme glutamate synthase to convert ammonia to glutamate. The energy for this comes ultimately from the oxidation of methanol to carbon dioxide, so the result is an excessive consumption of methanol.

But some organisms have a different pathway, using glutamate dehydrogenase, which is less able to scavenge small amounts of ammonia but is more energyefficient (and thus carbon-efficient). The possibility thus arose that the glutamate synthase gene in AS1 could be deleted, and the glutamate dehydrogenase gene substituted for it.

Luckily the well-studied Escherichia coli has the right gene, and Dr John Windass of ICI Corporate Laboratory was able to excise its gene and insert it into AS1. The greatest problem turned out to be how to isolate an AS1 mutant which had a deletion in the glutamate synthase gene: such mutants die immediately. However, ICI discovered a temperature dependent mutation - one where the glutamate synthase fails to operate above $37^{\circ} \mathrm{C}-$ and
Windass inserted the dehydrogenase gene into this mutant.

Above $37^{\circ} \mathrm{C}$ this modified strain uses the dehydrogenase pathway for assimilating ammonia; and over a two-months period the strain has proved to be stable.

Dr Windass, speaking at a recent biotechnology meeting in Roterdam, claimed that the engineered strain produced a "significant" improvement in carbon efficiency. Questioned whether a 3 to $5 \%$ improvement would justify the long toxicological studies that would be required if the strain was eventually to be employed, another ICI representative, Dr Peter Senior remarked that it would.

Toxicology studies are underway on the new strain, but it would be "at least five years" before it could be used. The strain could be adopted in the newly commissioned SCP plant, but there its efficiency would be sub-optimal, said Senior. "You have to design your plant around your bug".

In fact, Senior believes that the future of biotechnology will not be all plain sailing. "All the easy things have been done", he went on. "Biotechnology is grossly overselling its potential, and there is little likelihood on both scientific and economic grounds that we are staring a revolution in the face".

Conceptually the simplest biotechnical process was the growing and harvesting of single cell organisms, said Senior, yet "from my experience the single cell protein processes that have been developed at ICI have stretched the imagination and innovative skills of all those involved in their development to a degree that the conventional chemical industry has not experienced before'.

The ICI single cell protein process was first envisaged in 1968; in 1976 a sum of $£ 40$ million was sanctioned for the construction of a large plant, which is now on the point of production.

Robert Walgate

(C) 1980 Macmillan Journals Ltd 